\title{
BAIT-UL-HIKMAT: AN INSTITUTION OF LITERARY DEVELOPMENT UNDER ABBASIDS (751-1258AD)
}

*Mehmooda Irfan Wyne

\section{Abstract}

A recorded review subsequently gathers encounters of the past and passes them on to decide the course of our future activity. The instruction arrangement of the Muslims, throughout the hundreds of years delivered those thinkers, researchers, legal scholars, the men of letters and specialists in each field of information, who had made inconceivable commitments to workmanship, writing, verse, logic, medication, space science, geology, material science, speculative chemistry, mineralogy, legislative issues, and so on. These rich Muslims have commitments which made in the different branches of science filled in as a reason for the improvement of the present day science. None of these accomplishments would have been conceivable however for that dedication to learning and instruction which has described those individuals all through the history. The proposed research through the deductive approach is an attempt to investigate the training arrangement of the Muslims, its ideological bases esteems and qualities which affects the knowledge of the world positively. At the House of Wisdom, Important ideas from around the world came together and would be discussed threadbare. The period of Abbasid caliphs was the age of the highest evolution and greatest development of the Islamic society, knowledge and culture. It was the phase of modernization and scientific development in the history of Muslim world.

Key words: Bait-ul-Hikmat, Abbasids, Literature, Education, knowledge

\section{Introduction}

The Caliphate of the Abbasids was formed by the relatives of the Prophet Muhammad's most energetic uncle; whose name was "Abbas ibn ' Abd al-Muttalib in Kufa

\footnotetext{
*Associate Professor, Department of Islami Studies \& Comparative Religions, The Women University, Multan
} 
in $750 \mathrm{CE}$ who was then moved to Baghdad in 762 . It thrived for 200 years, yet gradually started deteriorating when the Trukish armed force ascended to power the Mamluks. In a time span of 150 years of gaining control of the Persian side, almost all the caliphates were compelled to surrender energy to neighborhood dynastic governors who just ostensibly recognized their power. ${ }^{1}$ With Abu'l Abbas as Saffah came to power the Caliphate of the House of al-Abbass. It was not mere dynastic change; it was a revolution in the history of early Islam, which affected all aspects of Islamic life, society, culture and civilization, arts and learning for all subsequent ages of Islamic history.It was out of such diverse influences and races that greatest civilization and culture off medieval Islam were built during the Abbasid Period, which determined the nature of Islamic thought and life of the Muslim people of the East down to the present days. The Golden Era or Age of Islamic educations was initiated in the middle of the $8^{\text {th }}$ century due to the rise of the Caliphate of the Abbasids and the shifting of the headquarters from Baghdad to Damascus. The Abbasids were affected by the injunctions of the Quran and the Hadith

\section{Holy Prophet (PBUH) \& literary advancement}

The Prophet's commitment to information and science is recognizing him from every other Teacher, and carrying him into the nearest partiality with the present day universe of thought. Medina, the seat of the religious federation of Islam, had, after the fall of Mecca, turn into the focal point of fascination, not to the hosts of Arabia just, but rather likewise to inquirers from abroad. Here rushed the Persian, the Greek, the Syrian, the Irakian, and African of different tones and nationalities from the north and the west. ${ }^{2}$ A few, undoubtedly, originated from interest, however, most came to look for learning and to tune in to the expressions of the Prophet of Islam.

He lectured of the estimation of learning: "Gain information, since he who obtains it in the method for the Lord plays out a demonstration of devotion; who talks about it, lauds the Lord; who looks for it, reveres God; who apportions direction in it, presents contributions; and who grants it to its fitting items, plays out 
a demonstration of commitment to God. Learning empowers its owner to recognize what is prohibited from what is not; it lights the best approach to Heaven; it is our companion in the abandon, our general public in isolation, our buddy when deprived of companions; it guides us to satisfaction; it supports us in wretchedness; it is our adornment in the organization of companions; it fills in as a defensive layer against our foes. With information, the hireling of God ascends to the statures of goodness and to an honorable position, partners with sovereigns in this world, and accomplishes the flawlessness of satisfaction in the home.

He would often say, "The ink of the scholar is more holy than the blood of the martyr"; and repeatedly impress on his disciples the necessity of seeking for knowledge "even unto China." "He who leaves his home in search of knowledge, walks in the path of God." "He who travels in search of knowledge, to him God shows the way to paradise."

The Koran itself bears testimony to the supreme value of learning and science. By commenting on the Surat-ul-alak,Zamakhshari thus explains the meaning of the Koranic words; "God taught human beings that which they did not know, and this testified to the greatness of His beneficence, for He has given to His servants' knowledge of that which they did not know. And He has brought them out of the darkness of ignorance to the light of knowledge, and made them aware of the inestimable blessings of the knowledge of writing, for great benefits accrue therefrom which God alone compasses; and without knowledge of writing no other knowledge(ulum) could be comprehended, nor the sciences placed within bounds, nor the history of the ancients be acquired and their sayings be recorded, nor the revealed books be written; and if that knowledge did not exist, the affairs of religion and the world, امور الد ين والد نيا could not be regulated."3

Up to the time of the Islamic Dispensation, the Arab world, properly so called, restricted with the peninsula of Arabia and some outlying tracts to the north-west and the 
north-east, had shown no signs of intellectual growth. Poetry, oratory, and judicial astrology formed the favorite objects of pursuit among the pre-Islamic Arabs, Science and literature possessed no votaries. But the words of the Prophet gave a new impulse to the awakened energies of the race. Even within his lifetime was formed the nucleus of an educational institution which in after years grew into universities at Bagdad and Salerno at Cairo and Cordova. ${ }^{4}$ The Umayyad embarked to make another culture by raising extraordinary royal residences, mosques, doctor's facilities and other open structures and by designating nonMuslims at different authoritative positions. The principal trait of Umayyad line was that they modernized their administration and the second was that they energized learning as indications of extravagance and for diversion. Prior to this, educators were not delegated or paid by the administration; they used to work at their own.

\section{Bait-ul-Hikmah: an Institution of Literary development}

The first academy, Bait-ul-Hikmah (House of Wisdom) was established by the Abassid Caliph Harun al-Rashid and was expanded by his son, the Caliph Al-Mamun. By the $9^{\text {th }}$ century, Baghdad had become a center of financial power and political prestige and intellectual pursuits flourished in numerous colleges, schools, hospitals, mosques and libraries. Amid the seventh century the Arab domain and Islamic space incorporated the domain of ancient Persian Empire and the vast majority of the Byzantine Empire. ${ }^{5}$ This brought about access to the riches and legacy of both Hellenistic and Eastern logic and learning. It was the house where both the non-Muslims and the Muslims convened together to research and bifurcate along with assembling most of the world's information into Arabic. Various accomplishments of antiquated circumstances which could have been lost were changed into Arabic and Persian which was later on changed over into Turkish, Hebrew and Latin. In the midst of this period the Muslim world was a cauldron of social orders which accumulated, mixed and inside and out impelled the data gotten from the old Roman, Chinese, Indian, Persian, Egyptian, North African, Greek and Byzantine improvements.

The fifth caliph of the Abbasid administration, Harun al-Rashid (786-809AD), is recognized as one of history's most noteworthy benefactors of human expressions and sciences. Under his control, Baghdad turned into the world's most imperative community for science, rationality, pharmaceutical, and instruction. The gigantic size of the caliphate 
implied that it had contact and imparted fringes to numerous inaccessible realms, so researchers at Baghdad could gather, interpret, and develop the learning of different civic establishments, for example, the Egyptians, Persians, Indians, Chinese, Greeks, Romans, and Byzantines. The successors of Harun al-Rashid, particularly al-Ma'mun (813-833), proceeded with his arrangements of supporting specialists, researchers, and researchers. AlMa'mun established the Bait al-Hikma, the House of Wisdom, in Baghdad. ${ }^{6}$ A library, an organization for interpreters, and from various perspectives an early type of college, the House of Wisdom facilitated Muslim and non-Muslim researchers who tried to decipher and assemble the total learning of mankind's history in one place, and in one dialect Arabic.

Consequently, Arabic turned into the artistic and logical most widely used language of the time. By uprightness of its root connection to the diverse Aramaic tongues, Arabic bound together the aggregate scholarly exertion of researchers into one lingo. Moreover, the new Arab/Islamic expert related effortlessly to these assorted gatherings and shared a number of the same social esteems.

At the House of Wisdom (Bait-ul-Hikmat), vital thoughts from around the globe met up. The presentation of Indian numerals, which have turned out to be standard in the Islamic and Western universes, extraordinarily helped in mathematics and logical disclosure. Researchers, for example, Al-Kindi altered science and incorporated Greek reasoning with Islamic idea. Al-Biruni and Abu Nasr Mansur among numerous different researchers made critical commitments to geometry and stargazing. Al-Khwarizmi, developing Greek numerical ideas, created Algebra (calculation" is a debasement of his name). Ibn al-Haytham made essential commitments to the field of optics, and is by and large held to have built up the idea of the logical strategy. ${ }^{7}$

Different astoundingly sensible improvements happened, especially in the field of cultivating. Upgraded strategies for water framework empowered more land to be produced, and new sorts of industrial facilities and turbines were used to decrease the prerequisite for work (however oppression was still extraordinarily typical in both the completely open and urban groups). Yields and developing systems were gotten from far-flung neighboring social orders. Rice, cotton, and sugar were taken from India, citrus normal items from China, and sorghum from Africa. Because of Islamic famers, these items at last progressed toward the 
West. Such Islamic progression would continue, even as the Abbasid government fell into clutter.

The work of Greek masterminds, for instance, Porphyry, Aristotle, Galen, and Hippocrates were implied Syriac and after that to Arabic. The weight of these materials were altogether destitute down and hence codified and reestablished with a specific Islamic Arabic identity.The first science to develop fully under caliphal patronage was medicine. It was partly due to the existence of Old Persian tradition, preserved in the great medical school and hospital at Jundeshahpur. ${ }^{8}$ Islamic researchers developed the works of Greek doctors, for example, Galen. Al-Razi (Rhazes, d. 925) was a chemist, doctor, and clinician who composed the principal restorative portrayal of smallpox and measles; he joined mental strategies with physiological clarifications. He additionally built up the train of pharmacology, discovered treatment for kidney stones, and utilized liquor as a sterile. In his medicinal reference book he included 50 preventative techniques for ladies. The Latin form of his work was distributed and utilized as content in Milan, Venice, and Basle. Ibn Sina (Avicenna) was a thinker, writer, and doctor who composed an immense group of drug. Ibn al-Haytham al-Khazin (Alhazen, d. 1039) composed The Book of Optics, in which he gave a point by point treatment of the life systems of the eye and accurately derived that the eye gets light from the protest saw, along these lines establishing the framework for current photography.In the therapeutic field, Yuhanna canister Masawayh (d. 857) started a legitimate and proficient procedure in Baghdad. ${ }^{9}$

- The immense thinker, al-Kindi (800-870) is viewed as the main real Arabic logician, who drew an expansive impact from both Aristotle and neo-Plutonian thought. $\mathrm{He}$ contributed a huge effect in the improvement of soothsaying, pharmaceutical and science.

- The Arabs were the originators of modern science and chemistry, which they called Al-Kimiya from which the words Alchemia and chemistry are derived. It began with Khalik bin Yazid bin Muawwya, who was the first alchemist of the Arabs.The first great Arab alchemist was Jabbir bin Hayan. He flourished at Kufa about 776, where he setup a laboratory. He discovered several chemical compounds. He wrote several books, three of them have been preserved till the present date, books are Kitan Al- 
Rahmah, Kitab Al-Tajmi (Book of Awareness) and Al-Zibak Al sharqi (on eastern mercury). "He improved on the methods for evaporation, sublimation, melting and crystallization".

- In the field of science and arithmetic, the three siblings Banu Musa-Muhammad, Ahmad, and al-Hasanwere pioneers and were the first to decipher Greek science in the ninth century. They extended their support to others and their work was later converted into Latin. Jabir Ibn Hayyan (Geber, d. 815) was a pioneer in the field of connected science and was viewed as the father of science.

- Al-Farabi (Alpharabus, d. 950) made striking commitments in the fields of science, solution, and music. Al-Khwarizmi (d. 840), with a Zoroastrian foundation and information of Sanskrit, made significant commitments in the fields of trigonometry, stargazing, and cartography.

- He established polynomial math and built up the idea of calculations (which are named after him) and acquainted the Arabic numeral framework with the world. AlIdris (d. 1166AD) was conceived and taught in the Andalus and was well known as a botanist, geographer, and restorative researcher.

- In the field of mechanical engineering, the thirteenth century researcher Al-Jaziri is outstanding for his work, The Book of Knowledge of Ingenious Mechanical Devices. He likewise inquired about the improvement of steam motor and pumping apparatus. Waterwheels to lift water from ground level to larger amounts, in light of the control of the weight of the water, were regular in Syria, Egypt, and Spain amid the brilliant period of Islam.

- Ibrahim Al-ghazari was the first Muslim who prepared Izterlaab and Yaqub bin Tariq got Hindu mathematics famous in the Arab community. In the courtroom of Caliph Abbas Al-Mansur, Yaqub bin Tariq met a Hindu (Kankah) who offered him a book called Siddhanta. Masnsur ordered Yaqub to translate it. ${ }^{10}$

- Abu Yusuf Bin Ishaq Al-Kindi, the first great Muslim philosopher was born at Kufa. Besides philosophy, Al-Kindi was greatly interested in astrology, medicine, mathematics, geography, music etc. He wrote about 263 works on various subjects 
which have not, however, survived to the present days except a few in their latin translations in Europe.

- Al-Farabi wrote about 100 books which include commentaries on Aristiotle and other Greek philosophers. Work on psychology, politics and metaphysics. His method was to combine the philosophies of Palto and Aristotle with sufism. Some of his writings were Risalah-fi-Ara Ahl-al Madina Al Fazila (a book of opinion of superior city), Al Siyasah Al-Madaniyah (a treatise on political economy), Risalah Fusus Al-Hikma (gems of wisdom) etc. Like other philosophers, Farabi was also interested in several other subjects including a book on music (Kitab Al-Musiqi Al Kabir). His writing however revealed him to be more of a Muslim and Sufi than a philosopher.

- Abu Ali Al-Husayn son of Abdullah, an Ismaeli, better known as Ibn -e-Sina was a Persian born near Bukhara in 980 and lived only in the east mostly in the court of the Samanid Kings of Bukhara. He was a philosopher, physician, philologist, and a poet.

- One of the most popular Muslim mathematicians is Al Kawarizmi, whose work has been translated into Latin. Al Kawarizmi laid the ground work for algebra and found methods to deal with complex mathematical problems, such as square roots and complex fractions. That's probably why he was called the father of Algebra.

\section{Translators of Bait-ul-Hikmat}

The following are the major contributors towards translation who worked under the Bait-ulHikmat:

- Hajaj Bin Yusaf Kufi

- Kasta Bin Looka Bin Ala Baki

- Abu Hasaan Salman

- Hunayn Bin Ishaq

- Sahal Bin Haroon

- Abu Jaffar Yahya Bin A’di

- Muhammad Bin Moosa Khuwarzami

- Hassan Bin Shaakir 
- Ahmad Bin Shaakir

- Ali Bin Al-Abass Bin Ahmad Johari

- Yaaqub Kindi

- Yohna Bin Ma'swiya Ibn-ul-Batareeq

- Muhammad Bin Shaakir

- Yahya Bin Abi Mansoor

These famous translators were the most literate people of the Darbaar of Ma'amun Ur Rasheed and the organizers of Bait-ul-Hikmat. Many of them were paid 2500/- month against their services. ${ }^{11}$ The vast contrast in intellectual activity could be demonstrated by just one example. In the ninth century, the library of the monastery of St. Gall was the largest in Europe. It boasted 36 volumes. At the same time, Cordoba's library contained over 500,000 !

Moreover, studying at colleges was first applied by Muslims. Universities first appeared in Muslims countries in the late 600s and the early 700s, while leading colleges, like Oxford and the University of Paris (French: Université de Paris), were founded in the thirteenth century.

\section{Muslim Scholars \& their work}

\section{Chemistry Scholars}

1. KIhalid bin Yazeed bin Mawaya (85 H, 704 E), wrote the book of chemistry titled Kitab Al Hararat, Al-Sahifatul Kibriya and Al-Sahifatul Saghira.

2. Jabir Bin Hayan $(200$ H, 815 E) wrote Al-Tadabir, Al-Masoom, Odafa Mazhara and Al-Mawazeen.

3. Zulnoon Al-Misary $(245 \mathrm{H}, 859 \mathrm{E})$ had written chemistry book namely AlRukan Al-Akbar and Al-Sakta fillsanata.

4. Al-Kindi, Yaqoob bin Ishaq $(260 \mathrm{H}, 873 \mathrm{E})$ wrote the chemistry book titled Al-Tanbhi Ali Hadul Kimiyain, Kimiyain Al-Attar and Al-Tasedaat. 
5. Ibn-e-Wahshit, Abu Bakar Ahmad Bin Ali (296 H, 908 E) wrote the chemistry book namely Kitabul Asool Al-kabeer, Al-Asool, Al-Sagheer and Al-Muzakara

6. Abu Quran Al-Naseebeeni died (296 H, 908 E) and he had written he book of chemistry Al-Khamair wa Al-Baloogh, Al-Tumiya, Sharah Al-Aseer

7. Usman bin Saweed Al-Khayme (298 H 910 E) wrote the chemistry book namely Al-Kabeerat, Al-Ahmar, Al-Taseed wa Al-Takteer, Al-Jaheem, AlAzam

8. Al-Razi Abu Bakar Muhammad Bin Zikriya (311 H, 923 E) wrote Al-Israr, Sir Al-Israr, Al-Hijar Al-Asghar.

9. Al-Mujrety Ahmad Bin Muslama (398 H, 1007 E) wrote Rutbatul Hakeem.

\section{Physics Experts}

1. Yaqoob Bin Ishaq Al-Kindi $(260 \mathrm{H}, 873 \mathrm{E})$ also wrote books of physics titled Al-Musootat Al-Tareeta and Al-Rasalatul Kibree.

2. Ahmad Bin Moosa bin Shakir died after $(270 \mathrm{H}, 883 \mathrm{E})$ who wrote with the help of two brothers a books of physics namely Heelbini Moosi

3. Sabit bin Qarata (288 H, 900 E) had written Rasalatul Qursatoon.

4. Qusta Bin Looqa Al-Balbaqi (300 H, 912 E) had written Al-Muraya AlMohraqta

5. Abul Qasim Al-Mujrity died nearly (398 H, 1007 E) had written Ilumul Heel and Ghayatul Hakeem.

6. Ibnesina (428 H, 1038 E) wrote Rasala fe Assbab Al-Raad and Al-Shafa

7. Abu Ali Al-Hassan bin Al-Hasam (429 H, 1038 E) wrote Al-Munazir, Rasalatul Zau and Rasala fe Zau Al-Kawakab.

8. Abu Al-Rehan Al-Barooni (440 H, 1038 E) had written Al-Isar Al-Bakita, Al-Kanoon Al-Masoodi and Al-Jamhir fe Al-Jawhir. 
9. Abu Hatim Al-Asafzari $(480$ H, 1087 E) had written Irshad Zui Al-Irfan Eli Sanatul Kabaan.

\section{Biologists and their work:}

1. Attar bin Muhammad Al hasib (821-206) had published "Manafal-Ahjar" in biology.

2. Al-Kindi (866-252) "Risala-tul-fil-madojazar” Allatul-Raud-walbaraq Wasalij.

3. Al-Jahiz (869-255) "Al-Tarbee-o-Wal-Tadreer".

4. Ikhwan-ul-Safah had published Al-Risalatul-Sania Min Rasail Ikhwan-ul-Safah (AlJismiatul-Tibiat). He had died in 4Ad.

5. Al-Astakhari had published (Masaalik-ul-Mumalik). He had died 300Ad, near to 912Ad.

6. Abu-Bak-Al-Razi (932-321) had published Risalah-fil-Behas-An-alarz Ahi Hajaniat-filAsal-Ume-Taiba.

7. Al-Hamdani, Ibn-ul-Haik (946-334) had published Ahsaul-aloom.

8. Al-Masoodi (957-346) Marwaju-Zahab-o-Madun-ul-Jareer and Al-Tankia-Wal-Israf.

9. Abn-e-Hoqal had published "Sorat-ul-arz (Atlas-ul-Islam)". He had died after (977-367).

10. Al-Seerafi (979-368) had published Silsatul Tawareekh.

\section{Arabian Scholars of Geography}

1. Moraj-Al-Sadoosi (810-195) had published "Kitab-ul-Anwar" in Geography.

2. Al-nazar bin Shameel (820-204) had published "Kitab-ul-Anwar" and "Kitabul-ShamsWal-Qamar".

3. Hisham-ul-Qalabi (820-204) had published "Kitab-ul-Aqaleem" Kita-ul-Baldan-alSagheera and "Kitab-ul-Bian-Kabeem".

4. Al-Khawarzmi Muhammmad bin Musa (834-232) had published "Surat-ul-Arz".

5. Al-Kindi (874-260) had published "Rasm-Mamoor-minal-arz".

6. Al-Marozi, Jafar Bin Ahmad (887-274) had published Masaalik-ul-Mumalik.

7. Al-Blazari (892-279) had published Fatooh-al-Baldan.

\section{MuslimLiterary impacts on Europe}

Islamic knowledge, science and technological advancements had a pervasive influence on the European Renaissance. Transmitting knowledge first through interactions in Hispania and Sicily, which Islamic armies conquered in the eighth and ninth centuries, and then 
through the Crusades and trade, Europe benefited heavily from the Islamic Empire's progressive thinking. Not only did Muslims preserve and translate ancient classical texts that inspired Renaissance thinkers, but they also invented the scientific method and modern university system, which led to the Scientific Revolution, and pioneered medical and agricultural techniques that improved the quality of life of European people during the Renaissance. Islamic contributions to Medieval Europe were numerous, affecting such varied areas as art, architecture, medicine, agriculture, music, language, education, law and technology. From the 11th to 13th century, Europe absorbed knowledge from the Islamic Civilizations. ${ }^{12}$ In the early 20th century the musicologist Henry George farmer wrote that a "Growing Numbers of Scholars recognized that the influence of the Muslim Civilization as a whole on Medieval Europe was enormous in such fields as science, philosophy, theology, literature, aesthetics, then has been recognized.

\section{Conclusion}

The period of Abbasid caliphs was the age of the highest evolution and greatest development of the Islamic society, knowledge and culture. It was the phase of modernization and scientific development in the history of Muslim world. Before Abbasids, the Muslim orthodox period was that of the political domination of the Arabs and they extended the boundaries of the Islamic state. However, in the period of Abbasids can observe the culmination of the evolution of Muslim society and culture, the perfection of Islamic theology and the efflorescence of Muslim arts, culture, science and the philosophy. The Abbasid caliphate, which ruled the Islamic world, over saw the golden age of Islamic culture.The Caliph paid special attention to education science, Philosophy and medicine. Harun al-Rashid and his successors, especially his son al-Mamun supported artists, scholars and scientist.The house of wisdom was a large library, an academy, an observatory and the translation bureau of the medieval period. It was a revolutionary step taken by the Abbasid caliph, where the scholars of different nations and countries gathered and presented their precious knowledge to the Muslims. 


\section{References:}

1. Amira K. Bennison, The Great Caliphs: The Golden age of the Abbasid Empire, Yale University press, London, 2010, pp. 119-125

2. John B. Hayes (editor), The Genius of Arab Civilization: Source of Renaissance, Mitt press, Cambridge, 1983, pp. 23-25

3. Michael Cook (editor), The New Cambridge History of Islam (vol. 6), Cambridge University press, Cambridge, 2010, p. 454

4. Syed Ameer Ali, The spirit of Islam, Lahore, 1967, pp. 360-362

5. John L. Eposite, The Islamic World: Past and Present (vol.1), Oxford University press, Oxford, 2004, p. 67

6. K. Atallah Ahmad, Bayt-al-Hikmah fi Asr-al-Abbasin, Dar-ul-Fikr press, Cairo, 1989 , pp. 34-40

7. Jonathan Lyons, The House of Wisdom: How the Arabs transformed Western Civilization, Bloomburg Publishing Pic, UK, 2009, pp. 68-72

8. M. M. Syed (editor), Encyclopedia of Islamic Science and Scientists (vol. 1), Anmol Publishers, New Delhi, 2009, pp. 223-225

9. E. J. Brill, Leiden, Bayt-al-Hikma in the Encyclopedia of Islam (vol.1), London, 1960, pp. 219-223

10. Abdul Ali, Indian Origin of Arab Islamic Scientific \& Literary Heritage, MD Publications, New Delhi, 2010, pp. 49-52

11. Philip K. Hitti, History of the Arabs: from the earliest Times to the Present, Macmillan press, UK. 1956, p. 245

12. K. Ali, A Study of Islamic History, Adam Publications, New Delhi, 2007, p. 109 